\title{
Survey for the Disease, Downy Mildew Incidence on Pearl Millet Cultivars in Rajasthan
}

\author{
K. K. Saini", A. C. Mathur and R. S. Sharma, Virendra Kumar and R.K. Bagari \\ Division of Plant Pathology, Rajasthan Agriculture Research Institute, (SKN Agriculture \\ University-Jobner), Durgapura, Jaipur, Rajasthan, India-302018, India \\ *Corresponding author
}

\begin{tabular}{l} 
K e y w o r d s \\
$\begin{array}{l}\text { Survey, pearl millet } \\
\text { cultivar, downy } \\
\text { mildew incidence }\end{array}$ \\
\hline Article Info \\
\hline $\begin{array}{l}\text { Accepted: } \\
\text { 18 May } 2020 \\
\text { Available Online: } \\
\text { 10 June } 2020\end{array}$ \\
\hline
\end{tabular}

\section{A B S T R A C T}

A total of 50 fields comprising of approximately 59 hectare area covering 11 tehsils with 24 villages of Bikaner, Jodhpur, Sikar, Jaipur and Alwar districts of Rajasthan at preboot to flowering stage were surveyed during kharif 2016 and 2017. Out of these, ten fields of Jodhpur district showed less than 10 per cent downy mildew incidence which was 9.6 per cent of the total fields observed during survey. The average downy mildew incidence in different districts varied from 9.87 to 17.95 per cent. The maximum average downy mildew incidence of 17.95 per cent was noticed in Bikaner district followed by Sikar (17.4\%), Jaipur (16.93 \%), Alwar (13.35 \%), and Jodhpur (9.87 \%). The overall mean of downy mildew incidence of five districts was 15.1 per cent. Out of 28 cultivars grown on farmer's fields, six cultivars were found free from downy mildew incidence. Eleven cultivars showed incidence up to 10 per cent and 11 cultivars showed more than 10 per cent incidence.

\section{Introduction}

Downy mildew, caused by Sclerospora graminicola (Sacc.) Schoret, is the most important and widespread biotic constraint to sustain high productivity of pearl millet [Pennisetum glaucum [(L.) R. Br.] hybrids in India.The disease is of wide occurrence in arid and semi-arid areas of Rajasthan. Hence, through understanding is required of actual distribution and prevalence of the disease in the major pearl millet growing areas of the
Rajasthan, Therefore, the present study was carried out to know the actual distribution and prevalence of the disease in the major pearl millet growing areas of the Rajasthan,

\section{Materials and Methods}

Survey was undertaken in the major pearl millet growing districts of Rajasthan namely, Bikaner, Jodhpur, Sikar, Jaipur and Alwar. Surveys were conducted at preboot to flowering stage in kharif 2016 and 2017. 
Observations for downy mildew incidence were recorded at every $10 \mathrm{~km}$ intervals, and fields on both sides of the road were scouted in a zigzag fashion. The selection of village and fields was done randomly. To assess the disease incidence, five fields were observed in each village and average incidence of the disease in each village was calculated. In each field, five random subplots (four at the corners and one in the middle) were selected, and within each subplot, a minimum of 50 plants were counted in 2-3 rows to record diseased and healthy plants. The sum totals of healthy and diseased plants from 5 subplots of each field were used to determine the downy mildew incidence percent. The per cent disease incidence was calculated as per formula given below

Per cent disease incidence $=\quad$\begin{tabular}{c} 
Number of infected plants \\
- \hdashline- Total number of plants observed $^{-}$
\end{tabular}

\section{Results and Discussion}

Survey for the occurrence of downy mildew of pearl millet was undertaken during kharif 2016 and 2017 in Bikaner, Jodhpur, Sikar, Jaipur and Alwar districts of Rajasthan at preboot to flowering stage. During the surveys, discussions were held with the farmers regarding occurrence and incidence of the disease downy mildew. As a result of discussion, it was revealed that the disease appeared in most of the fields wherever, pearlmillet crop has been grown regularly and area received average rainfall. Extensive surveys revealed that downy mildew of pearl millet appeared in all the districts surveyed. A total of 96 fields comprising of approximately 59 hectare area in 5 districts covering 11 tehsils with 24 villages of Rajasthan, were surveyed (Table 1 and Fig 1). Out of these, 10 fields of Jodhpur district showed less than 10 per cent downy mildew incidence which was 9.6 per cent of the total fields observed during survey. The average downy mildew incidence in different districts varied from 9.87 to 17.95 per cent. The maximum average downy mildew incidence of 17.95 per cent was noticed in Bikaner district followed by Sikar (17.4\%), Jaipur (16.93\%), Alwar (13.35\%), and Jodhpur $(9.87 \%)$.

The overall mean of downy mildew incidence of five districts was 15.1 per cent the above result are accordance with the scientist Rao et al., (2005) who surveyed 585 pearl millet fields in 16 districts of Rajasthan, $59 \%$ of these showed downy mildew infection. The mean downy mildew (DM) incidence across pearl millet cultivars over four seasons varied from low to moderate $(1-21 \%)$ in 14 districts, and minimum downy mildew (DM) was recorded in Alwar and Karauli districts.

Several Similar results reported by Sharma et al., (2012) who surveyed total of 97 fields in the eight districts of Uttar Pradesh and found 86 fields (89\%) with downy mildew incidence ranging from 2 to $100 \%$ with a mean incidence of $52 \%$ across infected fields downy mildew incidence was very high in the Hathras district with $100 \%$ incidence. None of the fields surveyed in Badaun, Bulandshehar, Mathura and Moradabad districts were free from downy mildew and the mean downy mildew incidence in these districts ranged from 45 to $83 \%$.

Sharma et al., (2012) surveyed pearl millet fields in Maharashtra, India during the rainy seasons of 2009 and 2010 to monitor on farm downy mildew (DM) incidence and assess the pathogenic diversity among native populations of Sclerospora graminicola. Of the 131 fields surveyed in seven districts in Maharashtra, DM was observed in 72 fields in the range of 1-90\%.Downy mildew was quite severe in Ahmednagar, Jalgaon, Aurangabad and Jalna districts with mean disease incidence of 56, 40, 35 and 32, respectively. 
Table.1 Status of downy mildew incidence in major pearl millet growing districts of Rajasthan (kharif 2016 and 2017)

\begin{tabular}{|c|c|c|c|c|c|c|c|c|}
\hline \multirow[t]{2}{*}{$\begin{array}{l}\text { S. } \\
\text { No. }\end{array}$} & \multirow[t]{2}{*}{ District } & \multirow[t]{2}{*}{$\begin{array}{l}\text { Tehsils } \\
\text { covered }\end{array}$} & \multirow[t]{2}{*}{ Village } & \multirow[t]{2}{*}{ Cultivar grown } & \multirow[t]{2}{*}{$\begin{array}{l}\text { No. of } \\
\text { Fields }\end{array}$} & \multicolumn{2}{|c|}{$\begin{array}{l}\text { DM } \\
\text { incidence } \\
(\%)\end{array}$} & \multirow[t]{2}{*}{ Mean } \\
\hline & & & & & & 2016 & 2017 & \\
\hline 1. & Bikaner & $\begin{array}{l}\text { i. Bikaner } \\
\text { ii. Lunkansar }\end{array}$ & $\begin{array}{l}\text { Beechwal\&Khara, } \\
\text { Bamanwali\&kakarwala }\end{array}$ & $\begin{array}{l}\text { Local, RHB 90, Unknownhybrid, Rewati } 2123 \text {, } \\
\text { Pioneer 7501, Pioneer 86M86, Proagro, Xylum } \\
\text { 86M66, Bioseed 8434, ICMH 356, PG 5848, }\end{array}$ & 10 & 18.6 & 17.3 & 17.95 \\
\hline 2. & Sikar & $\begin{array}{l}\text { i. Khandela } \\
\text { ii. Reengus }\end{array}$ & $\begin{array}{l}\text { Rampura\&Sukhpura, } \\
\text { Bagadi\&Nangal }\end{array}$ & $\begin{array}{l}\text { Pioneer 86M86, Nirmal hybrid, Unknown hybrid, } \\
\text { Bioseed 8486Local, RHB 121, Anmol }\end{array}$ & 10 & 16.5 & 18.3 & 17.4 \\
\hline 3. & Jodhpur & $\begin{array}{l}\text { i.Bhopalgarh } \\
\text { ii.Mandor }\end{array}$ & $\begin{array}{l}\text { Artiyakalan\&Bandra, } \\
\text { Alakhdara\&Keru }\end{array}$ & $\begin{array}{l}\text { Pioneer 86M86, Bioseed 8434, Pioneer 7501, } \\
\text { Proagro 7501, Local, MRB 2210, PG 5848, }\end{array}$ & 10 & 10.4 & 9.34 & 9.87 \\
\hline 4. & Alwar & $\begin{array}{l}\text { i. Bansur } \\
\text { ii. Kishangarh } \\
\text { Bas }\end{array}$ & $\begin{array}{l}\text { Khedla\&Mothuka, } \\
\text { Gothra\&Aundhra }\end{array}$ & $\begin{array}{l}\text { Unknown hybrid, Pioneer 86M86, Proagro 9450, JK } \\
\text { Agro, Raj 171, Xylum 86M66, Proagro }\end{array}$ & 10 & 12.3 & 14.4 & 13.35 \\
\hline 5. & Jaipur & $\begin{array}{l}\text { i. Chomu } \\
\text { ii. Phulera } \\
\text { iii. Jaipur }\end{array}$ & $\begin{array}{l}\text { Ghinoi\&Kanarpura, } \\
\text { Pratappura\&Gumaanpura, } \\
\text { Jobner,Bagas, Rainwal, } \\
\text { and Durgapura }\end{array}$ & $\begin{array}{l}\text { Rajlakshmi, Kaveribigboss, Pioneer78, Gurukripa, } \\
\text { Local,ICMH 356, Bioseed 8469, Bioseed } 8510 \text {, } \\
\text { Nirnal 1651, Anmol, PG 5848, PB } 106\end{array}$ & 10 & 16.3 & 17.56 & 16.93 \\
\hline & Total & 11 & 24 & 50 & & & & 15.1 \\
\hline
\end{tabular}

*All the data are mean of kharif 2016 and 2017 
Table.2 Downy mildew incidence in different cultivars recorded at farmers fields (kharif 2016 and 2017)

\begin{tabular}{|c|c|c|c|c|}
\hline $\begin{array}{l}\text { S. } \\
\text { No. }\end{array}$ & $\begin{array}{l}\text { Name of } \\
\text { cultivar }\end{array}$ & Area (ha.) & No. of Fields Observed & $\begin{array}{c}\text { DM incidence (\%) } \\
\text { Mean }\end{array}$ \\
\hline 1 & Rajlakshmi & 4.0 & 1.0 & 4.6 \\
\hline 2 & $\begin{array}{l}\text { Kaveri Big } \\
\text { Boss }\end{array}$ & 3.0 & 3.0 & 3.7 \\
\hline 3 & Pioneer-78 & 0.4 & 1.0 & 2.34 \\
\hline 4 & Guru Kripa & 2.0 & 1.0 & 4.3 \\
\hline 5 & Local & 10.0 & 17.0 & 16.7 \\
\hline 6 & Niramal Hybrid & 0.25 & 5.0 & 4.7 \\
\hline 7 & $\begin{array}{c}\text { Unknown } \\
\text { Hybrid }\end{array}$ & 9.0 & 12.0 & 19.45 \\
\hline 8. & Xylum 86M66 & 1.0 & 1.0 & 10.34 \\
\hline 9. & Proagro & 0.6 & 2.0 & 1.0 \\
\hline 10. & $\begin{array}{l}\text { Pioneer } \\
(86 \mathrm{M} 86)\end{array}$ & 3.0 & 3.0 & 0 \\
\hline 11. & Pro Agro 9450 & 5.0 & 1.0 & 0 \\
\hline 12. & JK Agro & 0.60 & 1.0 & 0 \\
\hline 13. & ICMH 356 & 5.0 & 6.0 & 27.3 \\
\hline 14. & HHB 67 & 3.0 & 5.0 & 3.7 \\
\hline 15. & Bioseed 8434 & 3.0 & 5.0 & 21.0 \\
\hline 16. & Bioseed 8469 & 1.6 & 3.0 & 0 \\
\hline 17. & Bioseed 8486 & 0.25 & 2.0 & 0 \\
\hline 18. & Bioseed 8510 & 6.0 & 1.0 & 0 \\
\hline 19. & Anmol & 1.0 & 3.0 & 16.2 \\
\hline 20. & PG 5848 & 3.0 & 2.0 & 17.3 \\
\hline 21. & PB 106 & 5.0 & 4.0 & 17.7 \\
\hline 22. & Proagro 7501 & 4.0 & 5.0 & 16.0 \\
\hline 23. & RHB 90 & 0.25 & 6.0 & 19.3 \\
\hline 24. & RHB121 & 4.0 & 4.0 & 12.6 \\
\hline 25. & Nirmal 1651 & 2.0 & 3.0 & 6.45 \\
\hline 26. & MRB 2210 & 1.0 & 1.0 & 2.34 \\
\hline 27. & Raj 171 & 2.0 & 3.0 & 5.7 \\
\hline 28. & Rewati 2123 & 1.0 & 1.0 & 1.0 \\
\hline
\end{tabular}

*All the data are mean of kharif 2016 and 2017 


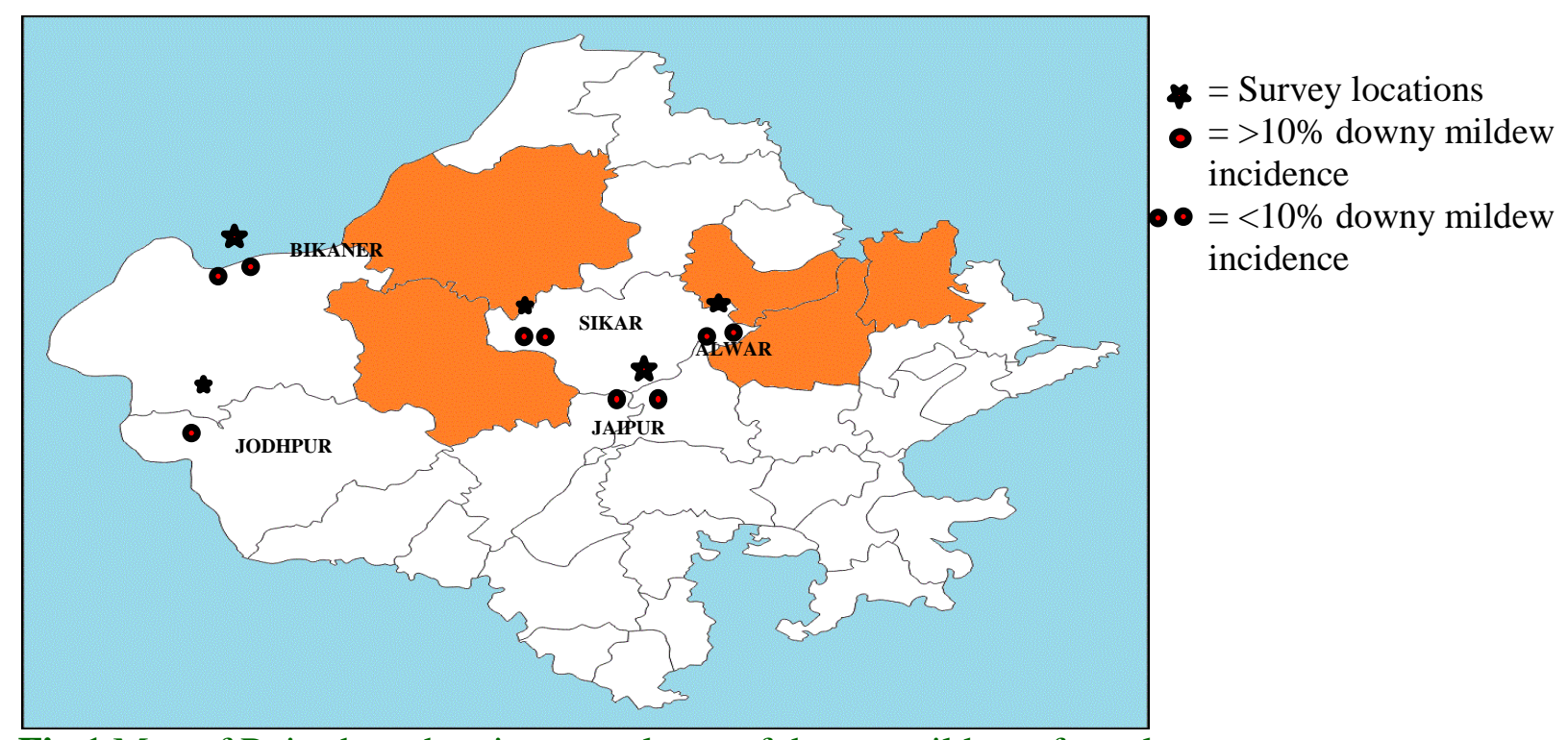

Fig.1 Map of Rajasthan showing prevalence of downy mildew of pearl millet (Kharif, 2016 and 2017)

Out of 28 cultivars grown on farmer's fields, six cultivars were found free from downy mildew incidence. Eleven cultivars showed incidence up to 10 per cent and 11 cultivars showed more than 10 per cent incidence (Table 2). The maximum incidence was recorded in cultivar ICMH $356(27.3 \%)$, followed by Bioseed 8434 (21\%), Unknown Hybrid (19.45\%), RHB 90 (19.3\%), PB 106 (17.7 \%), PG 5848 (17.3\%), Local (16.7\%), Anmol (16.2\%), Pro Agro 7501 (16\%), RHB 121 (12.6\%), Xylum 86M66 (10.34\%), Nirmal 1651 (6.45 \%), Raj 171 (5.7\%), Nirmal Hybrid (4.7\%), Rajlakhsmi (4.6\%), Guru Kripa (4.3\%), Kaveri big boss and HHB 67 (3.7\%), MRB 2220 and Pioneer 78 (2.34\%), and lowest incidence (1\%) was recorded in Proagro and Rewati 2123. These results were accordance with Thakur et al., (1997), Thakur et al., (2003), Rao et al., (2007) and Sharma et al., (2012).

From the experimental results it was concluded that the disease appeared in most of the fields wherever, pearl millet crop has been grown regularly and area received average rainfall.
Therefore, downy mildew is the most important and widespread biotic constraint to sustain high productivity of pearl millet hybrids in India.

\section{Acknowledgement}

The authors are grateful to Director and Head, Division of Plant Pathology, Rajasthan Agricultural Research Institute, Durgapura and SKN Agriculture University- Jobner for providing necessary facilities to carry out the experiment.

\section{References}

Rao, V.P., Thakur, R.P., Rai, K.N., Sharma, Y.K. (2005). Downy mildew incidence on pearl millet cultivars and pathogenic variability among isolates of Sclerospora graminicola in Rajasthan. International Sorghum and Millets Newsletter.46: 107-110.

Rao, V.P., Kadwani, D.L., Sharma, Y.K., Sharma, R. and Thakur, R.P. (2007).Prevalence of Pearl millet Downy mildew, Sclerospora graminicola, in Gujarat and Pathogenic 
Characterization of its Isolates.In. $J . P l$. Prot. 35(2): 291-295.

Sharma, R., Gate, V. L., Kishore Babu, B., Panduranga Rao, V. and Ghughe, S.S. (2012). Prevalence and Pathogenic Diversity in Pearl millet Downy Mildew Pathogen Populations in Maharashtra, India.In. J. Pl. Prote. 40(4): 306-311.

Thakur, R.P. and Rao, V.P. (1997).Variation in virulence and aggressiveness among pathotypes of Sclerospora graminicola on pearl millet. Indian Phytopathology, 50:41-47.

Thakur, R.P., Rao, V.P., Amruthesh, K.N., Shetty, H.S. and Datar, V.V. (2003). Field surveys of pearl millet downy mildew effects of hybrids, fungicide and cropping sequence. Journal of Mycology and Plant Pathology 33(3): 387-394.

\section{How to cite this article:}

Saini. K. K., A. C. Mathur, R. S. Sharma, Virendra Kumar and Bagari. R.K. 2020. Survey for the Disease, Downy Mildew Incidence on Pearl Millet Cultivars in Rajasthan. Int.J.Curr.Microbiol.App.Sci. 9(06): 2092-2097. doi: https://doi.org/10.20546/ijcmas.2020.906.256 